\title{
The Effect of Corporate Social Performance and Financial Performance On Corporate Social Responsibility (CSR) Disclosure As an Intervening Variable Toward Firm Value
}

\author{
FANISYA ALYA PUTERI* \\ LINDRIANASARI \\ NINUK DEWI KESUMANINGRUM \\ FARICHAH \\ Universitas Lampung
}

\begin{abstract}
This study aims to examine the effect of CSP and Financial Performance to Firm Value through CSR Disclosure as an intervening variable in an attempt to attain sustainability. The research object is the mining sector companies listed in Indonesia Stock Exchange (BEI) for the 2014-2016 period. The CSP is measured from The Corporate Performance Rating Program (the acronym is PROPER) by The Ministry of Environment in Indonesia. The Return determines the Financial Performance on Assets (ROA). CSR Disclosure is measured by CSR Disclosure score based on the guidelines known as the Global Reporting Initiative (GRI-G4). The Tobin's $Q$ is used as the indicator of the Firm Value. The result of data analysis shows that CSP and Financial Performance has a positive significant effect on the CSR disclosure. On one side, the CSP has a significant effect on the CSR Disclosure, so do the Financial Performance. In another side, the CSP has no significant effect on the Firm Value, but Financial Performance has a positive significant effect on the Firm Value. Further, the CSR disclosure has a positive significant effect on Firm Value. As a result, CSR disclosure as an intervening variable in the relationship between CSP and Financial Performance toward Firm Value is significant.
\end{abstract}

Keywords: Corporate Social Performance, Financial Performance, CSR Disclosure, Firm Value

Intisari: Penelitian ini bertujuan untuk menguji pengaruh CSP dan Kinerja Keuangan terhadap Nilai Perusahaan melalui Pengungkapan CSR sebagai variabel intervening dalam upaya untuk mencapai keberlanjutan. Objek penelitian adalah perusahaan sektor pertambangan yang terdaftar di Bursa Efek Indonesia (BEI) untuk periode 2014-2016. CSP diukur dari Program Penilaian Peringkat Kinerja Perusahaan (akronimnya PROPER) oleh Kementerian Lingkungan Hidup di Indonesia. Pengembalian menentukan Kinerja Keuangan pada Aset (ROA). Pengungkapan TSP diukur dengan skor Pengungkapan TSP berdasarkan pedoman yang dikenal sebagai Global Reporting Initiative (GRI-G4). Q Tobin digunakan sebagai indikator Nilai Perusahaan. Hasil analisis data menunjukkan bahwa CSP dan Kinerja Keuangan memiliki pengaruh signifikan positif terhadap pengungkapan TSP. Di satu sisi, CSP memiliki efek signifikan pada Pengungkapan CSR, begitu juga Kinerja Keuangan. Di

*Corresponding author: fanisyalyaputeri@ gmail.com 
sisi lain, CSP tidak memiliki pengaruh signifikan terhadap Nilai Perusahaan, tetapi Kinerja Keuangan memiliki pengaruh positif yang signifikan terhadap Nilai Perusahaan. Selanjutnya, pengungkapan TSP memiliki pengaruh positif yang signifikan terhadap Nilai Perusahaan. Akibatnya, pengungkapan CSR sebagai variabel intervening dalam hubungan antara CSP dan Kinerja Keuangan terhadap Nilai Perusahaan adalah signifikan.

Kata Kunci: Kinerja Sosial Perusahaan, Kinerja Keuangan, Pengungkapan CSR, Nilai Perusahaan

\section{Introduction}

In the last decade, the objectives of business is sustainability that produces pressure from various stakeholders, namely customers, employees, suppliers, non-profit organizations, and government pushes companies in Indonesia to be responsible not only on economic issues but also for social and environmental of companies which already comply with government rules and regulations on the implementation of social responsibility. To achieve sustainable development, companies are not only required on the value of corporate responsibility which is reflected in the financial statement of the company but also must be based on the triple bottom line dimensions. This concept emphasizes responsible to people (social), planet (environment), and profit. Based on the dimensions, financial circumstance cannot guarantee the value of the company grows (sustainable). Corporate sustainability will be ensured if companies pay attention to the social and environmental dimensions.

At the global order and also in Indonesia, the definition of social responsibility, in general, refers to the ISO 26000 Guidance for Social Responsibility, the responsibility of an organization for the impacts of its decisions and activities on society and the environment, through transparent and ethical behavior that contributes to sustainable development, health and the welfare of society. It takes into account the expectations of stakeholders; is in compliance with applicable law and consistent with international norms of behavior; and is integrated throughout the organization and practiced in its relationships. As mentioned in accounting magazine (IAI Global) that during this time of sacrifice for corporate social responsibility (CSR) activities are generally 
recognized and treated as periodic load (expense) that reduces profit and owner's equity. Preferably, the sacrifice and the effort should be recognized as a green investment that increases the value of assets (green assets) and reduces corporate earnings (IAI Global Magazine, 2017).

According to Barusman and Lindrianasari (2016), Corporate Social Responsibility (CSR) is a concept that describes that an entity has broad responsibilities for all stakeholders in all aspects of corporate activities that include economic, social, and environmental (three bottom line). One of the central themes brought by the social performance concept is how companies can measure the actions and results of the social action of the company, as well as companies, can measure other operational activities. It has become essential for the company, due to the implementation of CSR programs companies financed by the company funding sources are limited. While fund issued by the company's CSR activities are not small numbers. Therefore, social activities funded by the company should be able to measure the results. Also, the company also wanted to know how that activity impacts the performance of the company.

The companies who make CSR as their part of the business strategy will get a positive effect on their performance because the social cost spent in these activities will make their business more efficient and create better value (Lin and Amin, 2017). Furthermore, from an economic perspective, the company will reveal some information if such information could increase the value of the company (Basalamah and Jermias, 2005) and it can be said that the social performance of companies is the assessment of a company's performance that be observed from CSR social role it plays in the community. Thus, a company which implements CSR and components properly, the corporate social performance will increasingly raise. This study aims to examine and explain the effect of corporate social performance and financial performance with CSR disclosure as an intervening variable toward firm value. 


\section{Theoretical Framework and Hypothesis Development}

The theory of legitimacy is closely related to stakeholder theory. The theory of legitimacy states that organizations are continually looking for ways to ensuring their operations are within the limits and norms prevailing in the community. In the perspective of the theory of legitimacy, a company will voluntarily report on its activities if management considers that this is what the community expects (Craig, 2000). Furthermore, stakeholders are all internal and external parties who have a good relationship are affecting or affected, is directly or indirectly by a variety of decisions, policies, and operating company. This theory stated that the success and the life and death of a company depend on its ability to balance diverse interests from stakeholders. If the company can balance the interests of its stakeholder, the company will receive on-going support to increase growth in market share, sales, and profits. In the perspective of stakeholder theory, society and the environment is a core stakeholder company to be aware of (Lako, 2011). Based on the disclosure that the companies have to do, the signal Theory is rooted in centralized pragmatic accounting theory and put attention to the influence of information on changes in user of information behavior. One of the information that can be used as a signal is disclosure which is performed by an issuer. Disclosure of this information can later affect the rise and fall of the issuer's corporate securities price. Disclosure of accounting information can give a signal that the company has good prospects (good news) or otherwise bad signals (bad news) in the future (Rokhlinasari, 2016).

\subsection{Corporate Social Performance}

Turban and Greening (1996) define Corporate Social Performance as construction that emphasizes the corporate responsibility to many stakeholders, such as employees and society at large, in addition to their traditional responsibilities to the shareholders of the economy. Based on the concept of Triple Bottom Line or three primary factors of operation within its relation to environment and people (People, Profit, and Planet) confirms that companies are not simply ignoring the role of stakeholders and shareholders with only the pursuit of company's profit. Also, if a company wants to maintain its survival, the company has to pay attention and be involved in the 
fulfillment welfare of the society (people) and contribute actively in maintaining environmental sustainability (planet).

\subsection{Financial Performance}

The company's financial performance is a formal business conducted efficiently and the company to evaluate the effectiveness of internal company activities that have been implemented in certain periods. Companies' profitability performance information mainly needed to assess potential changes in the economic resources may be controlled in the future (Basalamah and Jermias, 2005). Performance fluctuations information useful for predicting the company's capacity to generate cash flow from existing resources, in addition to such information could also be useful in the formulation of judgment about the effectiveness of the company in the use of additional resources.

\subsection{Corporate Social Responsibility (CSR)}

Implementation of CSR requires useful reporting in informing and communicating forms of accountability to stakeholders. Therefore, CSR reporting is so strategic in initiating stakeholder opinion to improve the company's reputation significantly (Kartini, 2009). CSR disclosure is part of reporting transformed into obligatory with the passage of Limited Liability Company Law No. 40 of 2007 which is described in article 66 paragraph (2) that in addition to submitting financial statements, the company is also required to report on the implementation of social and environmental responsibility. The disclosure aims to provide a signal to stakeholders that the company has integrated CSR in every aspect of its operations, so it is expected to have positive implications for the company's reputation in the capital market. CSR disclosures based on GRI are economic, environmental, labor practices and decent work, human rights, society and product responsibility dimensions. GRI is a pioneer in developing sustainability reporting framework containing economic, environmental and social reports as a comparison of financial statements (Lindrianasari, 2007). The company will be more valuable than other companies if concerned about the impact of the corporate activity. 


\subsection{Firm Value}

Firms value are characteristic of companies that tend to provide an evaluation of the company's performance from both internal and external. To determine the market value of the company is used financial ratios. Then from this ratio is an indication of the management regarding the investors' assessment of corporate performance in the past and the possibility of economic prospects in the future. Managers and investors are usually interested in the company's market value. The firm value is useful for management to motivate and fix the GCG implementation to value the company is always good (Pamungkas \& Muid, 2013).

\subsection{Research Framework}

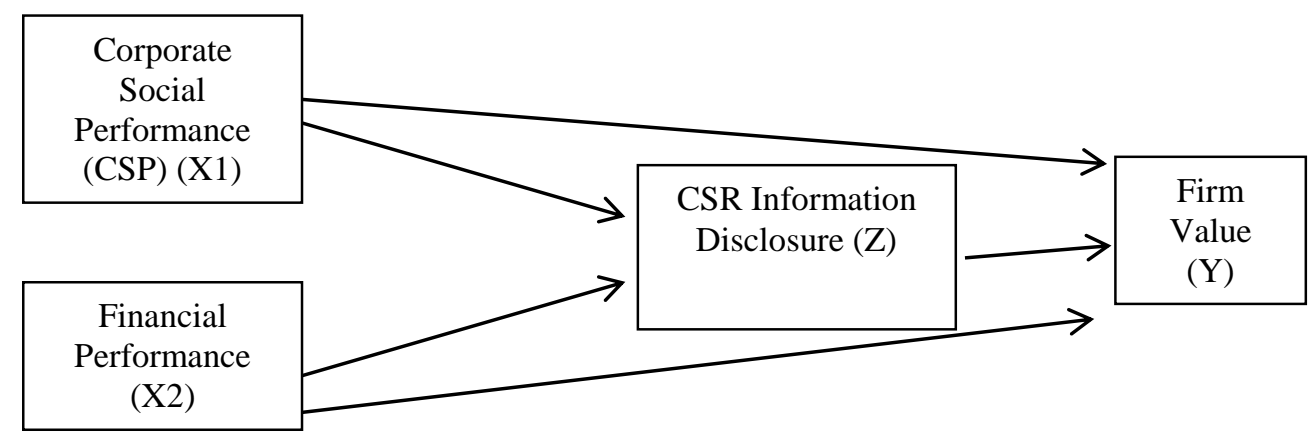

A company is said to have good value if the company's performance is good. The company's value can be reflected in its share price. Therefore, the company which has a high stock value can be said that it also has a good value. Mangos \& Lewis (1995) explained the necessity of a socio-economic paradigm to analyze the selection of accounting practices by management. They suggest the need for consideration of the corporate social responsibility (CSR) factor when we examine the positive accounting theory. With this analysis, it will be able to help management understand their responses to socio-economic issues and their relationship to firm value.

The main purpose of the company is to increase the firm value. The firm value will be guaranteed to grow sustainably if companies pay attention to performance financial and economic, social and environmental dimensions because of sustainability 
is a balance between economic, social and environmental interests community. Therefore, with good financial performance and CSR practices, it's expected the value of a company will be appraised well by the investor.

Other factors that influence the relationship of social and financial performance with firm value, in this study include the CSR disclosure as an intervening variable. Selection of CSR variables is based on the results of research on the impact of social performance and allocation of CSR costs on the performance of the company that shows that the allocation of CSR influences financial performance, so CSR allegedly participates strengthen or weaken the influence. The influence of social performance and financial performance on firm value with CSR disclosure as an intervening variable.

\subsection{Hypotheses Development}

\subsubsection{The Relation of Corporate Social Performance (CSP) to CSR Disclosure}

A company is said to have good value if the company's performance is good. The company's value can be reflected in its share price. Therefore, the company which has a high stock value can be said that it also has a good value. Hastuti (2016) found that the percentage of management ownership and the type of industry significantly influence company policy in disclosing social information. This means that the larger holdings of managerial ownership in the company, the more manager of the company will disclose social information.

Mangos \& Lewis (1995) explained the necessity of a socio-economic paradigm to analyze the selection of accounting practices by management. They suggest the need for consideration of the corporate social responsibility (CSR) factor when we examine the positive accounting theory. With this analysis, it will be able to help management understand their responses to socio-economic issues and their relationship to firm value. In Rokhlinasari (2016) stated that companies with high quality tend to use social accounting and corporate environments as a diversion from traditional financial reporting. On the other hand, low-quality companies choose consistently by limiting the disclosure of accounting information to external parties. The more a company 
implements CSR well, then the corporate social performance will increasingly raise. Then the hypothesis made is as follows:

$\boldsymbol{H}_{\text {I. }}$ Corporate Social Performance (CSP) has a significant positive effect on CSR Disclosure.

\subsubsection{The Relations of Financial Performance to CSR Disclosure}

Tsoutsoura (2004) stated that the company which has a solid financial performance would have more resources to invest in the domain of social performance. The signal theory states that the company provides signals to parties outside the company with the goal to enhance shareholder value. In addition to the required financial information, the company also conducts voluntary disclosure. Stakeholder theory holds that companies must make-social disclosure as one of the responsibilities to stakeholders.

Eduardus and Juniarti (2016) stated that firms with better financial performance potentially have more funding resources to invest in corporate social performance. For example, companies with good financial performance will have funds available to build relationships with customers through the manufacture of safe products consumed, improve relations with employees through the provision of pension funds, and also improve the environment by processing waste operational for environmentally friendly. A company who has a good financial performance is expected to have good disclosure of its social responsibility. The hypothesis made is as follows:

$\boldsymbol{H}_{2}$. Financial Performance has a significant positive effect on CSR Disclosure.

\subsubsection{The Relations of Corporate Social Performance (CSP) to Firm Value}

According to the Karimi (2009) in Septiadini (2010), corporate social performance is a performance assessment of a company CSR through the social role, and it plays in society. The literature study conducted by Finch (2005) in Dahlia and Siregar (2008) explained that the company's goal of using sustainability reporting framework is as the way company used to manage relations with its stakeholders. Furthermore, within 
the social performance conducted by the company is expected to provide concrete evidence that the company's production process is not only profit-oriented but also pay attention to social issues, to increase stakeholder trust that will impact on increasing firm value through increased investment. It's impacting on increasing in corporate profits.

If the social performance is well-implemented, a firm value will be increased through the stakeholder who invests in a company that trusts the social performance which is impacting the society. Based on the explanation above, then the hypothesis made as follows:

$\boldsymbol{H}_{3 .}$ Corporate Social Performance (CSP) has a significant positive effect toFirm

Value.

\subsubsection{The Relations of Financial Performance to Firm Value}

The theory is that put forward by Modigliani and Miller states that the value of the firm is determined by the earnings power of the firm's assets. Positive results indicate that the higher the earnings power, the more efficient the asset turnover and or the higher the profit margin obtained by the company. This will have an impact on company value. In research of Suparjan and Ali (2012) stated that the effect of financial performance toward firm value indicates that the more financial performance raising, the firm value will be increased. But, a study conducted by Hermawan and Maf'ulah (2014) found that ROA had no significant effect on firm value.

On the other hand, Susilaningrum (2017) stated that the primary purpose of a company is to increase the value of the company. If the financial performance of a company that is described as ROA is higher, then the value of the company also increases, because the value of the company is determined by earnings power of the company's assets. The results of this study indicate that there is a positive influence ROA on firm value.

The firm value will grow sustainable if the company can improve its financial performance. Based on the explanation above, the hypothesis proposed in this study is as follows: 
$\boldsymbol{H}_{4}$. Financial Performance has a significant positive effect on Firm Value.

\subsubsection{The Relations of CSR Disclosure to Firm Value}

Rika and Islahudin (2008) research found that CSR does not affect the firm value. This may be caused by the lack of disclosure of CSR that happen on manufacturing firms in Indonesia. According to Dahlia and Siregar (2008), the company's goal of using sustainability reporting framework is as the way companies use to manage relationships with their stakeholders. Therefore, with the disclosure of Sustainability Report conducted by the company's production process is not only profit-oriented, but also pay attention to social issues, and environment, so to increase stakeholders trust that will impact on increasing firm value through increased investment impact increase in corporate profits. The CSR disclosure will be an effect to stock performance on a company. Based on the explanation above, then the hypothesis made as follows:

$\boldsymbol{H}_{5 .}$ CSR disclosure has a significant positive effect on Firm Value.

2.6.6 The Relations of Corporate Social Performance and Financial Performance to Firm Value through CSR Disclosure as Intervening Variable

The direct effect of CSR disclosure is not significant to the firm value. Research Rika and Islahudin (2008), also found that CSR does not affect the firm value. This means that CSR is not a factor that determines the value of a good company. This may be caused by the lack of disclosure of CSR that happen on manufacturing firms in Indonesia. Another possibility is for CSR in Indonesia does not meet the standards of GRI (Rika and Islahudin, 2008). The results of this study differ from research Rustiarini (2010) who found a positive effect of CSR on firm value. This study uses the CSP and financial performance as an independent variable and CSR disclosure as an intervening variable with the idea that the market will provide a positive appreciation that may impact the company ' $s$ improved performance and the ability to earn income. The sustainability of the company will only be ensured if it takes into the social and environmental dimensions surrounding its operational impacts (Susilaningrum, 2017). Thus it can be concluded CSR disclosure has an essential 
effect for the achievement of firm value in addition to social performance and financial performance. Based on the theory and research, the hypothesis proposed in this study is as follows:

$\boldsymbol{H}_{6 .}$ Corporate social performance and financial performance have a significant positive effect on Firm Value through CSR disclosure as an intervening variable.

\section{Research Methods}

\subsection{Population and Research Samples}

What companies sample in this study is manufacturing companies listed on the Indonesia Stock Exchange (BEI) in the year 2014-2016 and meet the criteria for purposive sampling. The criteria are:

1. All manufacture companies which listed in IDX.

2. Followed the assessment of PROPER from 2014 to 2016.

3. Published financial statements and annual report for the year of observation consecutive years from 2014 to 2016.

4. Presented Corporate Social responsibility Report in its annual report in a row from 2014 to 2016.

\subsection{Dependent Variable}

The dependent variable of this study is Firm Value. It can be obtained by using the model of Tobin's Q as below:

$$
\mathrm{Q}=\frac{(\text { Equity Market Value }+ \text { Total Debt })}{\text { Total Asset }}
$$

\subsection{Independent Variables}

\subsubsection{Corporate Social Performance}

The independent variable used in this research is a social performance which is measured through company achievement in following PROPER. PROPER is a program that is one of the efforts undertaken by the Ministry of Environment (KLH) 
to encourage the company's arrangement in environmental management through information. PROPER performance ranking system is divided into five colors:

1. Gold: extra very good score $=5$

2. Green : Very good score $=4$

3. Blue : Good score $=3$

4. Red : Bad score $=2$

5. Black: Very bad $\quad$ score $=1$

Information:

Gold: Has consistently demonstrated the environmental excellence in the process production or service, carrying out an ethical and responsible business to society.

Green: Has done environmental management more than the regulations required through the implementation of environmental management systems, efficient utilization of resources through 4R efforts (reduce, reuse, recycle, recovery) and perform social responsibility well.

Blue: Has undertaken the required environmental management effort as stipulated in the legislation.

Red: Environmental management is not done under the conditions set out in the laws.

Black: Accidentally committed a law or omission resulting in pollution or environmental damage or violation of the laws' rules.

\subsubsection{Financial Performance}

This study uses the Return on Assets (ROA) as an indicator of financial performance measurement. Based on Tandelilin (2010) ROA is a profitability ratio which illustrates the extent to which the ability of assets owned by the company can generate profits. The formula to find the total Return on Assets can be used as follows:

$$
R O A=\frac{\text { Net Income After } \text { Tax }}{\text { Total Asset }} \times 100
$$




\subsection{Intervening Variable}

Theoretically, intervening variables affecting the relationship between the dependent and independent variables, but cannot be seen, measured and manipulated (Rulyanti, 2013). In this study, the disclosure of corporate social responsibility is used as an intervening variable. Corporate Social Responsibility Disclosure Index calculation formula is as follows:

$$
C S R D I=\frac{\text { Number of items disclosed by the company }}{\text { number of items required by GRI-G4 (91 items) }}
$$

\subsection{Data Analysis Method}

This research used two regression models. The first regression model was used to test the effect of corporate social performance and financial performance to CSR Disclosure. While the second regression test used to determine the effect of corporate social performance, financial performance, and CSR Disclosure to firm value. The regression models are as follows:

$$
\begin{aligned}
& \text { CSRDI }=\alpha+\beta 1 \text { SOCIAL }+\beta 2 \text { PROFIT }+\varepsilon 1 \ldots \ldots \ldots \ldots \ldots \ldots \ldots \ldots \ldots \ldots \ldots \\
& \text { VALUE }=\alpha+\beta 3 \text { SOCIAL }+\beta 4 \text { PROFIT }+\beta 5 \text { CSRDI }+\varepsilon 2
\end{aligned}
$$

Information:

SOCIAL

PROFIT

CSRDI

VALUE

$\alpha$

$\beta 1, \beta 2, \beta 3, \beta 4, \beta 5$

$\varepsilon 1, \varepsilon 2$
$=$ Corporate Social Performance

$=$ Financial Performance

$=$ Corporate Social Responsibility Disclosure Index

$=$ Firm Value

$=$ Constants

$=$ Coefficients of exogenous and endogenous variables

$=$ Error or regression residual value 


\section{Results and Discussion}

The population in this study are all 151 manufacturing companies listed on the Indonesia Stock Exchange in 2014-2016. Based on the selection process, obtained as many as 65 companies are divided into 165 data selected as a sample. The author conducted a purposive sampling method with the following details:

Table 1.

Selection of Company Samples

\begin{tabular}{ll}
\hline Criteria & Total \\
\hline All manufacture companies which listed in IDX in 2014-2016 (3 & 453 \\
years) & \\
Did not follow the assessment of PROPER from 2014 to 2016. & $(288)$ \\
Did not publish financial statements and annual report for the year of & 0 \\
observation consecutive years from 2014 to 2016. & \\
Did not presented corporate social responsibility report in its annual & 0 \\
report in a row from 2014 to 2016. & 165 \\
\hline Total sample
\end{tabular}

\subsection{Descriptive Statistics}

This study uses descriptive statistics to explain the description of 165 sample data from 55 companies. Description of the sample in the form value of maximum, minimum, mean, and standard deviation. Description of descriptive statistics can be seen in the following table:

Table 2.

Result of Descriptive Statistics Regression Model

\begin{tabular}{|l|l|l|l|l|l|}
\hline & & & & & \\
& $\mathrm{N}$ & Minimum & Maximum & Mean & Std. Deviation \\
\hline SOCIAL & 165 & 2,0000 & 5,0000 & 3,006061 &, 4485338 \\
PROFIT & 165 &,- 2214 &, 4317 &, 061329 &, 1062395 \\
VALUE & 165 &, 0544 & 18,6404 & 2,316820 & 3,1036776 \\
CSRDI & 165 &, 0879 &, 5604 &, 239425 &, 1023016 \\
Valid N & 165 & & & & \\
(listwise) & & & & & \\
\hline
\end{tabular}

Source: Data processed (2018). 
From table 2 above described as follows:

1. From table 2, the mean of the Corporate Social Performance which proxied as PROPER valuation is equal to 3.006061 . The data proves that social performance in companies are mostly rated blue companies or has a value of 3 in the PROPER valuation. The minimum value of 2,0000 is found in some companies, and the maximum value is 5,0000. The data prove that social performance in the smallest firms acquire companies ranked red or have a value of 2 in the PROPER assessment, and social performance in the companies highest ranked as a gold company or has a value of 5 in the PROPER ratings.

2. From table 2, variable Financial Performance (PROFIT) proxied as Return on Assets (RoA) has a minimum value -0,2214 and maximum value 18,6404. Further, the average value of ROA shows a value of 0,061329 is a demonstration of the ability of management to manage the company's capital invested in the total assets to generate profits for investors (holders of bonds and shares). Every single rupiah average capital yield a profit of $\mathrm{Rp} 0,061329$ for investors. Furthermore, with a standard deviation of 0,1062395 which means an increase in the maximum and minimum variable is equal to 0,1062395 financial performance of the average value with a sample size of 165 .

3. From table 2, variable Firm Value (VALUE) has the minimum value of 0,0544, and maximum value obtained amounted to 18,6404 , standard deviation obtained is 3,1036776 , and the mean value of 2,316820 . This shows that the average value owned by manufacturing companies in Indonesia Stock Exchange amounted to $231,68 \%$ or can be interpreted that the companies are quite good because they have a much larger company than $100 \%$. This means investing in an asset generates a profit that gives a higher value than an investment expense, and this will generate new investment.

4. From table 2, variable CSR Disclosure Index (CSRDI) has a minimum value of 0,0879 and the maximum value 0,5604 with an average value of 0,239425 
with 165 samples, which means that the average manufacturing company in Indonesia reveals the company's CSR $23,9 \%$ of the 91 items.

\subsection{Classic Assumption Test}

\subsubsection{Normality Test}

The normality test aims to test whether, in the regression model, the intruder or residual variable has a normal distribution. In principle to know the normality of data can be detected in two ways that are by graph analysis and statistical test. The way graphics analysis sees the spread of data (dots) on the diagonal lines of the graph. The basis of decision making according to Ghozali (2016), if the data spread around the diagonal line and follow the diagonal line, or histogram graph shows the normal distribution pattern, then the regression model meets the assumption of normality. Kolmogorov-Smirnov statistical test method was seen from the level of significance. This test is performed before the data is processed. Data is stated to be normal distribution if Kolmogorov-Smirnov significance value> 0,05.

From the output of SPSS, it appears that the dots (data) spread around the diagonal line and follow the direction of the diagonal line. This shows that the regression model meets the assumption of normality. Based on SPSS output results in the residual normality test table, it can be seen that the significance value (Asymp. Sig.2-tailed) is 0,200 for the first regression and 0,200 for second regression. Due to the significance of more than $0.05(0,200>0.05)$, then the data is otherwise normally distributed.

\subsubsection{Multicollinearity Test}

The multicollinearity test aims to test whether the regression model is found the correlation between independent variables. Moreover, the detection of multicollinearity also aims to avoid habits in the process of making conclusions about the influence of the partial test of independent variables to the dependent variable. A good regression model should not occur the correlation between independent variables. If independent variables are correlated to each other, then those variables 
are not orthogonal. According to Ghozali (2016), orthogonal variables are independent variables whose correlation values between all independent variables equals 0 . A regression model is said to be free of multicollinearity if the tolerance value is above 0.10 and VIF is below 10 .

Based on SPSS output results, multicollinearity test results show that VIF value is less than 10 for the first regression $(1,086 ; 1,086<10)$ and also for the second regression $(1,229 ; 1,263 ; 1,410<10)$ and Tolerance value is greater than 0,10 for the first regression $(0,921 ; 0,921>0,10)$ and also for the second regression $(0,814 ; 0,791$; $0,709>0,10)$. Thus, it can be concluded that the results of the test show free regression model of multicollinearity or there are no symptoms of multicollinearity.

\subsubsection{Autocorrelation Test}

The autocorrelation test using test run, through a test run we can know whether there is a correlation between high residual or not. If there is no correlation between the residuals, it is said that the residual is random. A model declared free of autocorrelation in the test run test if the significance level of residual tested more than 0,05 .

The first regression indicates that the value Asymp. Sig. (2-tailed) of 0,912 $(0,912>0,05)$ and for the second regression indicates that the value Asymp. Sig. (2tailed) of $0,912(0,912>0,05)$. From the results of those regressions can be concluded that this research model does not occur autocorrelation or free from autocorrelation.

\subsubsection{Heteroscedasticity Test}

This test aims to test whether the regression model occurs inequality variance of the residuals of the observations to other observations (Ghozali, 2016). One way to detect the presence or absence of heteroscedasticity is through the scatterplot graph. The conclusion was drawn by looking at the distribution point on the scatterplot from the analysis. There are certain patterns, such as dots that form a particular pattern is regular (wavy, widened, and narrowed). If there is no clear pattern as well as the 
points spread above and below the number 0 on the $\mathrm{Y}$ axis, then there is no heteroscedasticity (Ghozali, 2016).

From scatterplot graph heteroscedasticity test for first and second regressions show that the dots randomly spread and spread both above and below the number 0 on the axis $\mathrm{Y}$. This indicates that there is no heteroscedasticity in regression models 1 and 2.

\subsection{Discussion of Research Result}

If seen from R-Square model 1 value of 0,282 indicates that the proportion of influence of SOCIAL and PROFIT variable to CSRDI variable is $28,2 \%$, meaning that the social and profit performance has a proportion of influence on CSR disclosure of $28,2 \%$ while the remaining $71,8 \%(100 \%-28,2 \%)$ is influenced by other variables that are not in the linear regression model. Further, from R-Square model 2 value of 0,465 indicates that the proportion of influence of SOCIAL, PROFIT, and CSRDI variable to VALUE variable is $46,5 \%$, \%, meaning that the social and profit performance has a proportion of influence on CSR disclosure of $46,5 \%$ while the remaining $53,5 \%(100 \%-46,5 \%)$ is influenced by other variables that are not in the linear regression model.

F statistical test or ANOVA test is the initial stage of identifying a feasible or unexpected regression model. To test the model, this test illustrates that all the independent variables included in the model have simultaneously influenced the dependent variable (Ghozali, 2016). If the value of $F$ in ANOVA test significant at the $5 \%$ probability level, it can be said that all independent variables simultaneously affect the dependent variable. From the first regression model the calculated $F$ value of 33,175 with a significance level of 0.000 and from the second regression model the calculated $F$ value of 48,456 with a significance level of 0.000 . Hence the significance of less than 0,05, it can be said that model 1 and model 2 , all the independent variables simultaneously affect the dependent variable. 


\subsection{Path Analysis}

The path coefficient is calculated by making two structural equations which are:

Model 1: CSRDI $=-2,553+0,313$ SOCIAL $+1,472$ PROFIT $+\varepsilon 1$

Model 2: VALUE $=0,388+0,062$ SOCIAL $+5,261$ PROFIT $+0,360$ CSRDI $+\varepsilon 2$

First model of regression equation:

Table 3.

T-test Result (CSRDI)

\begin{tabular}{|l|r|r|r|r|}
\hline \multirow{2}{*}{ Model } & \multicolumn{2}{|c|}{ Unstandardized Coefficients } & \\
\cline { 2 - 3 } & \multicolumn{1}{|c|}{ B } & Std. Error & \multicolumn{1}{c|}{ T } & \multicolumn{1}{c|}{ Sig. } \\
\hline 1 (Constant) & $-2,553$ &, 202 & $-12,660$ &, 000 \\
SOCIAL &, 313 &, 068 & 4,613 &, 000 \\
PROFIT & 1,472 &, 286 & 5,141 &, 000 \\
\hline
\end{tabular}

Source: Data processed (2018).

Second model of regression equation:

Table 4.

T-test Result (VALUE)

\begin{tabular}{|l|l|l|l|l|}
\hline \multirow{2}{*}{ Model } & \multicolumn{2}{|l|}{ Unstandardized Coefficients } & & \multirow{2}{*}{ Sig. } \\
\cline { 2 - 3 } 1 (Constant) & B & Std. Error & T &, 732 \\
SOCIAL &, 388 &, 530 &, 732 &, 465 \\
PROFIT &, 062 &, 134 &, 463 &, 644 \\
CSRDI & 5,261 &, 575 & 9,146 &, 000 \\
\hline
\end{tabular}

Source: Data processed (2018).

The effect of mediation shown by multiplication coefficient (ab) needs to be tested with Sobel test as follows: standard error of indirect effect coefficient (sab). 


\subsubsection{Path Analysis Result 1}

Figure 1.

Path Analysis Result Social

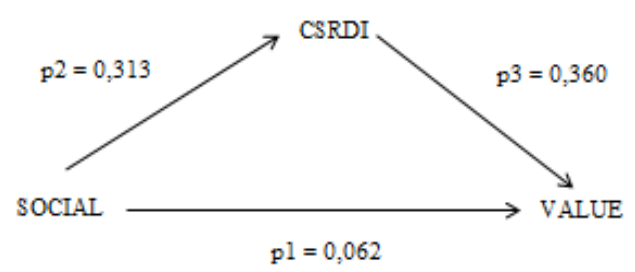

The magnitude of the indirect effect is calculated by multiplying the p2 and $\mathrm{p} 3$ ie $(0,313 \times 0,360=0,112)$. Calculate the standard error of the coefficient indirect effect (Sp2p3):

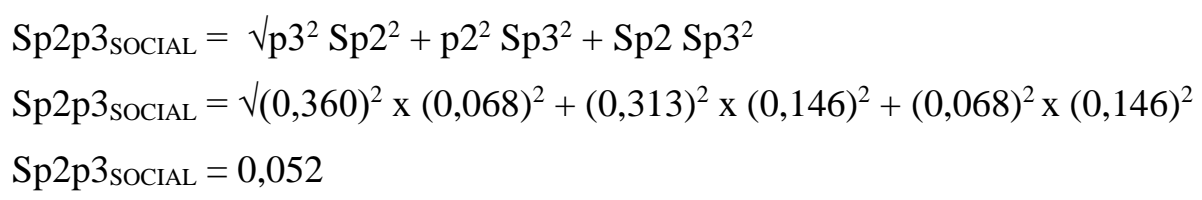

Then the statistic $\mathrm{t}$ calculated by:

$\mathrm{t}=\mathrm{P} 2 \mathrm{P} 3 / \mathrm{Sp} 2 \mathrm{p} 3$

$\mathrm{t}=0,112 / 0,052$

$\mathrm{t}=2,134$

\subsubsection{Path Analysis Result 2}

Figure 2.

Path Analysis Results PROFIT

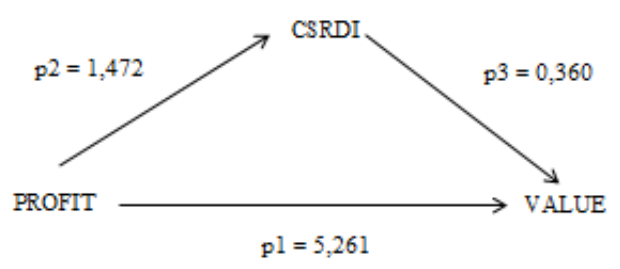

The magnitude of the indirect effect is calculated by multiplying the p2 and $\mathrm{p} 3$ ie $(1,472 \times 0,360=0,529)$. Calculate the standard error of the coefficient indirect effect (Sp2p3):

$\mathrm{Sp} 2 \mathrm{p} 3_{\text {PROFIT }}=\bigvee_{\mathrm{p}} 3^{2} \mathrm{Sp} 2^{2}+\mathrm{p} 2^{2} \mathrm{Sp} 3^{2}+\mathrm{Sp} 2 \mathrm{Sp} 3^{2}$ 
Sp2p3 $3_{\text {PROFIT }}=\sqrt{ }(0,360)^{2} \times(0,286)^{2}+(1,472)^{2} \times(0,146)^{2}+(0,286)^{2} \times(0,146)^{2}$

$\mathrm{Sp} 2 \mathrm{p} 3_{\text {PROFIT }}=0,241$

Then the statistic $t$ calculated by:

$\mathrm{t}=\mathrm{P} 2 \mathrm{P} 3 / \mathrm{Sp} 2 \mathrm{p} 3$

$\mathrm{t}=0,529 / 0,241$

$\mathrm{t}=2,186$

Table 5.

Research Results

\begin{tabular}{|c|c|c|c|c|}
\hline Hypothesis & Statement & Coefficient & Sig. & Conclusion \\
\hline $\mathrm{H}_{1}$ & $\begin{array}{c}\text { Corporate Social Performance } \\
\text { (CSP) has a significant positive } \\
\text { effect to CSR Disclosure }\end{array}$ & 0,313 & 0,000 & Supported \\
\hline $\mathrm{H}_{2}$ & $\begin{array}{c}\text { Financial Performance has a } \\
\text { significant positive effect to CSR } \\
\text { Disclosure }\end{array}$ & 1,472 & 0,000 & Supported \\
\hline $\mathrm{H}_{3}$ & $\begin{array}{c}\text { Corporate Social Performance } \\
\text { (CSP) has a significant positive } \\
\text { effect on Firm Value }\end{array}$ & 0,062 & 0,644 & $\begin{array}{c}\text { Not } \\
\text { Supported }\end{array}$ \\
\hline $\mathrm{H}_{4}$ & $\begin{array}{c}\text { Financial Performance has a } \\
\text { significant positive effect on Firm } \\
\text { Value }\end{array}$ & 5,261 & 0,000 & Supported \\
\hline $\mathrm{H}_{5}$ & $\begin{array}{c}\text { CSR disclosure has a significant } \\
\text { positive effect on Firm Value }\end{array}$ & 0,360 & 0,015 & Supported \\
\hline
\end{tabular}

Table 6.

Research Results

\begin{tabular}{|c|c|c|c|}
\hline Hypothesis & Statement & t-count & Conclusion \\
\hline \multirow{3}{*}{$\mathrm{H}_{6}$} & $\begin{array}{c}\text { Corporate social performance (CSP) has a } \\
\text { significant positive effect on Firm Value } \\
\text { through CSR disclosure as an intervening } \\
\text { variable. }\end{array}$ & 2,134 & Supported \\
\cline { 2 - 4 } & $\begin{array}{c}\text { Financial performance has a significant positive } \\
\text { effect on Firm Value through CSR disclosure as } \\
\text { an intervening variable. }\end{array}$ & 2,186 & Supported \\
\hline
\end{tabular}

4.5 Corporate Social Performance (CSP) has a significant positive effect to CSR Disclosure

The result of the statistical t-test which shows that the independent variable Corporate Social Performance (CSP) affects CSR Disclosure. It is proved by the 
probability significance value ( $\mathrm{Sig}$. T) for the independent variable is 0,000 . This regression result shows that the coefficient of CSP is less than 0,05. So, the hypothesis is accepted. This research is in line with the research of Rokhlinasari (2016) that stated that companies with high quality tend to use social accounting and corporate environments as a diversion from traditional financial reporting. Therefore, the more a company implements corporate social performance well, then the disclosure of its CSR will increasingly raise.

\subsection{Financial Performance has a significant positive effect to CSR Disclosure}

The result of the statistical t-test which shows that the independent variable Financial Performance affects CSR Disclosure. It is proved by the probability significance value (Sig. T) for the independent variable is 0,000 . This regression result shows that the coefficient of Financial Performance is less than 0,05. So, the hypothesis is accepted. This supports the research of Eduardus and Juniarti (2016) stated that firms with better financial performance potentially have more funding resources to invest in corporate social performance and more voluntarily disclose their social responsibility activities. Hence, the company who has a good financial performance is expected to have a good social performance also.

\subsection{Corporate Social Performance (CSP) has a significant positive effect on Firm Value}

The result of the statistical t-test which shows that the independent variable Corporate Social Performance (CSP) does not affect Firm Value. It is proved by the probability significance value (Sig. T) for the independent variable is 0,644 . This regression result shows that the coefficient of CSP is more than 0,05. So, the hypothesis is not accepted. This research is in line with the research of Saridewi and Koesrindartoto (2014) shows that social performances for companies in Indonesia do not give short-term impact to the stock performance. Also, the implementation of social performance is not the main factor determining the performance of a company. 


\subsection{Financial Performance has a significant positive effect on Firm Value}

The result of the statistical t-test which shows that the independent variable Financial Performance affecttps Firm Value. It is proved by the probability significance value (Sig. T) for the independent variable is 0,000 . This regression result shows that the coefficient of Financial Performance is less than 0,05. So, the hypothesis is accepted. The result of this study is in line with previous research conducted by Suparjan and Ali (2012) that found the effect of financial performance toward firm value indicates that the higher of financial performance value then the firm will have a good value. This study indicates that the increase of stock performance follows the magnitude management's ability to manage its capital invested in the total assets to generate profits for all investors (both bond and stockholders).

\subsection{CSR Disclosure has a significant positive effect on Firm Value}

The result of the statistical t-test which shows that the independent variable Financial Performance has an impact on Firm Value. It is proved by the probability significance value (Sig. T) for the independent variable is 0,000 . This regression result shows that the coefficient of CSR Disclosure is less than 0,05. So, the hypothesis is accepted. The result of this study is in line with previous research conducted by Finch (2005) that stated the company's goal of using sustainability reporting framework is as the way companies use to manage relationships with their stakeholders. This study shows that the existence of Corporate Social Performance (CSP) is done better by some company that affects its stock performance.

\subsection{Corporate Social Performance (CSP) and Financial Performance have a significant positive effect on Firm Value through CSR disclosure as an intervening variable}

The value of t-count for Corporate Social Performance (CSP) to firm value through CSR Disclosure is equal to 2,134 or greater than $t$ table at a significance level 0,05 that is 1,96 . This shows that there is a significant relationship between Corporate Social Performance (CSP) to firm value through CSR Disclosure. Then, t-count for the 
variable Financial Performance proxied as Return on Assets (RoA) to firm value through CSR Disclosure is equal to 2,186 or higher than t table with level 0,05 that is 1,96. It means that there is a significant relationship between Financial Performance to firm value through CSR Disclosure. So, the hypothesis is accepted. The result of this study is in line with previous research conducted by Suparjan and Ali (2012) that stated the more companies do the social activity, the disclosure of their social responsibility is more exhaustive and will affect the stock value of the company.

In one side, from the hypothesis 3 which is not supported that found the corporate social performance has no significant effect to firm value and when it has been intervening by CSR disclosure, it affects the relationship between corporate social performance and firm value and they have stronger relationships. Furthermore, corporate social performance is still obligated to be implemented and also obligated for CSR to be disclosed. Those obligatory give the information to stakeholders and external relations in intention to increase the firm value. Generally, the intervening analysis is accepted to show the relation. In another side, from the hypothesis 4 which is supported that found financial performance has a positive effect to firm value and when it has been intervening by CSR disclosure, it affects the relationship between financial performance and firm value but not as stronger as when they have a direct relation. Thus it can be concluded that CSR disclosure has an essential effect on the achievement of firm value in addition to social performance and financial performance.

\section{Conclusion, Limitations, and Implications}

The conclusion of this research is: 1) corporate social performance has a significant positive effect on CSR disclosure. 2) financial performance has a significant positive effect on CSR disclosure. 3) corporate social performance has no significant positive effect on firm value. 4) financial performance has a significant positive effect on firm value. 5) CSR disclosure has a significant positive effect on firm value. 6) corporate social performance and Financial performance has a 
significant positive effect on firm value through CSR disclosure. Furthermore, corporate social performance is obligated to be implemented and also obligated for CSR to be disclosed. Those obligatory give the information to stakeholders and external relations in intention to increase the firm value. Because of that, the intervening analysis is accepted to show the relation. Hence, financial performance has a positive effect to firm value, and when it has been intervening by CSR disclosure, it affects the relationship between financial performance and firm value but not as stronger as when they have a direct relation. Then, it can be concluded CSR disclosure has an essential effect for the achievement of firm value in addition to social performance and financial performance.

Limitations in this research are: 1) the population in this study is only limited to the company included in the manufacturing company during the research period. 2) financial performance which has been researched only return on asset.

In future research there are several things to be noted, including 1) further research may add another independent variable that can affect the CSR disclosure and or the firm value. 2) pay attention to financial performance besides return on assets, or add another profitability ratio. By using several ratios then the condition of the company can be seen wiser.

\section{References}

Basalamah, Anies S., and Jermias, Johnny. 2005. Social and Environmental Reporting and Auditing in Indonesia: Maintaining Organizational Legitimacy. Gadjah Mada International Journal of Business. 7(1): 109-127.

Barusman, Yusuf Sulfarano, and Lindrianasari. 2016. Determinant of Corporate Social Responsibility: Case from Indonesia. Ekuitas: Jurnal Ekonomi dan Keuangan. 20(1): 37-52.

Craig, Deegan. 2000. Financial Accounting Theory. McGraw Hill Book Company, Sydney.

Eduardus, Edbert and Juniarti. 2016. Kinerja Sosial Perusahaan dan Kinerja Keuangan Perusahaan yang Diukur Menggunakan Tobin's q. Business Accounting Review. Universitas Kristen Petra. 4(1): 517-528. 
Finch, N., 2005. Sustainability Reporting Frameworks. Paper presented at the Allied Academies 8th International Internet Conference, 18 - 31 July. ISSN: 1445-3037.

Ghozali, I. 2016. Analisis Multivariate dengan Program IBM SPSS 23. $8^{\text {th }} \quad$ Edition. Issuing Agency of Universitas Diponegoro. Semarang.

Kartini, Dwi. 2009. Corporate Social Responsibility Transpormasi Konsep Sustainability Management dan Implementasi di Indonesia. Printed. 1; $\quad$ Bandung, 2009.

Lako, A. 2011. Dekonstruksi CSR dan Reformasi Paradigma Bisnis dan

Akuntansi. Jakarta. Erlangga.

Lako, A. 2017, July-August. Krisis Ekologi dan Urgensi Akuntansi Hijau. http://iaiglobal.or.id/v03/majalah-akuntan/files/Juli-Agustus2017/ (Accessed on Wednesday, September $27^{\text {th }}$ 2017).

Lin, Huey-Yeh and Nursyamsi Amin. 2017. The Relationship Between Corporate Social Performance and Financial Performance: Evidences from Indonesia and Taiwan. European Journal of Business and Social Sciences. 5(10): 28-40. ISSN: 2235 $-767 X$.

Lindrianasari. 2007. Hubungan Antara Kinerja Lingkungan dan Kualitas Pengungkapan Lingkungan dengan Kinerja Ekonomi Perusahaan di Indonesia. Jurnal Akuntansi \& Auditing Indonesia. 11(2): 159-172.

Mangos, Nicholas C. and Neil R. Lewis. 1995. A Socio-Economic Paradigm For Analysing Managers' Accounting Choice Behaviour. Accounting, Auditing, and Accountability Journal. 8(1): 38-62.

Pamungkas and Muid, Dul. 2013. Pengaruh Struktur Kepemilikan, Leverage dan Return On Assets (ROA) Terhadap Kebijakan Dividen. Jurnal Akuntansi. 2(3): 1-11.

Rokhlinasari, Sri. 2016. Teori-Teori dalam Pengungkapan Informasi Corporate Social Reponsiblity Perbankan. Al-Amwal: Jurnal Ekonomi Islam dan Perbankan. IAIN Syekh Nurjati Cirebon.

Rulyanti, Susi Wardhani. 2013. Pengaruh CSR Disclosure Terhadap Nilai Perusahaan Dengan Kinerja Keuangan Sebagai Variabel Intervening (Studi Kasus Perusahaan Manufaktur Yang Terdaftar di BEI). Jurnal Ekonomi dan Akuntansi Manajemen. ISSN: 1412-5366.

Saridewi, Putri N. and Deddy Koesrindartoto. 2014. The Link between Social, Environmental to Financial Performances of Companies in Indonesia. International Conference on Trends in Economics, Humanities, and Management (ICTEHM'14): Pattaya (Thailand). 
Fanisya Alya Puteri et all.

Suparjan, Andika and Ali, Sandy Mulya. 2012. Pengaruh Kinerja Sosial dan Kinerja Keuangan Perusahaan Dengan Pengungkapan Corporate Social Responsibility Sebagai Variabel Intervening Terhadap Nilai Perusahaan. Media Riset Akuntansi, Auditing \& Informasi. 12(3).

Tandelilin, Eduardus. 2010. Analisis Investasi dan Manajemen Portofolo. Yogyakarta: BPFE.

Turban, D. B., \& Greening, D. W. 1996. Corporate social performance and organizational attractiveness to prospective employees. Academy of Management Journal, 40(3). 
The Indonesian Journal of Accounting Research - Sep, Vol. 21, No.3, 2018

intentionally blank 